\title{
əSevere Convective Windstorms in Europe: Climatology, Preconvective Environments, and Convective Mode
}

\author{
GeOrge P. PACEY, ${ }^{\mathrm{a}, \mathrm{c}}$ DAVID M. SChUltz, ${ }^{\mathrm{a}, \mathrm{b}}$ AND Luis GARCiA-CARreras ${ }^{\mathrm{a}}$

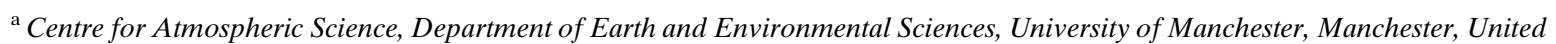 \\ Kingdom \\ ${ }^{\mathrm{b}}$ Centre for Crisis Studies and Mitigation, University of Manchester, Manchester, United Kingdom
}

(Manuscript received 12 May 2020, in final form 18 November 2020)

\begin{abstract}
The frequency of European convective windstorms, environments in which they form, and their convective organizational modes remain largely unknown. A climatology is produced using 10233 severe convective wind reports from the European Severe Weather Database between 2009 and 2018. Severe convective wind days have increased from 50 days $\mathrm{yr}^{-1}$ in 2009 to 117 days $\mathrm{yr}^{-1}$ in 2018, largely because of an increase in reporting. The highest frequency of reports occurred across central Europe, particularly Poland. Reporting was most frequent in summer, when a severe convective windstorm occurred every other day on average. The preconvective environment was assessed using 361 proximity soundings from 45 stations between 2006 and 2018, and a clustering technique was used to distinguish different environments from nine variables. Two environments for severe convective storms occurred: Type 1, generally low-shear-highCAPE (convective available potential energy; mostly in the warm season) and Type 2, generally high-shear-low CAPE (mostly in the cold season). Because convective organizational mode often relates to the type of weather hazard, convective organizational mode was studied from 185 windstorms that occurred between 2013 and 2018. In Type- 1 environments, the most frequent convective mode was cells, accounting for $58.5 \%$ of events, followed by linear modes ( $29 \%$ ) and the nonlinear noncellular mode (12.5\%). In Type-2 environments, the most frequent convective mode was linear modes (55\%), followed by cells (36\%) and the nonlinear noncellular mode (9\%). Only $10 \%$ of windstorms were associated with bow echoes, a lower percentage than other studies, suggesting that forecasters should not necessarily wait to see a bow echo before issuing a warning for strong winds.
\end{abstract}

SIGNIFICANCE STATEMENT: One of the hazards of convective storms (those that can produce lightning, hail, tornadoes, etc.) is strong winds, which were associated with 78 confirmed fatalities in Europe between 2009 and 2018 . We mapped 10233 reports of strong convective winds over Europe during this 10 -yr period, finding that all European countries (except Iceland) experienced strong convective winds, with the greatest threat over central Europe. Such windstorms were reported every other day on average during the summer, but occurred during all seasons, including winter. We found specific indicators of the conditions and types of storms that produced the strong winds. These results are important because forecasters will better understand the conditions in which such convective windstorms occur, leading to better forecasts and warnings.

KEYWORDS: Convective storms; Wind gusts; Severe storms; Wind effects; Storm environments; Convective lines

\section{Introduction}

One of the hazards of severe convective storms is strong winds. Nontornadic convective windstorms in the United States during the 10 years 1998-2007 killed 191 people (Schoen and Ashley 2011). For comparison, during the 10 years from 2009 to 2020 , nontornadic convective windstorms were associated with 78 confirmed fatalities in Europe (source: data from the European Severe Weather Database, http://www.eswd.eu).

๑ Denotes content that is immediately available upon publication as open access.

\footnotetext{
${ }^{\mathrm{c}}$ Current affiliation: Institut für Meteorologie, Freie Universität Berlin, Berlin, Germany.

Corresponding author: Prof. David M. Schultz, david.schultz@ manchester.ac.uk
}

Both the United States and Europe have comparable areas (around $10^{7} \mathrm{~km}^{2}$ ) and populations with the same order of magnitude (300 million in 2007 for the United States versus 741 million in 2016 for Europe). Specifically, these statistics result in an estimate of one fatality per 1.6 million people in the United States and one fatality per 9.5 million people in Europe. Therefore, the rates of fatalities by nontornadic convective windstorms in the two areas are of the same order of magnitude.

Nevertheless, the amount of convective storm research in general across Europe presently lags that of the United States (e.g., Doswell 2003, his section 4; Antonescu et al. 2016, 2017; Groenemeijer et al. 2017). This lag has not always been the case. As Brooks et al. (2019, p. 18.4) write, "It is not unreasonable to say that the best understanding of severe convective

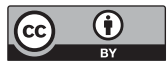

This article is licensed under a Creative Commons Attribution 4.0 license (http://creativecommons.org/ licenses/by/4.0/). 
storms, or at least, tornadoes, at the end of World War I was found in Europe, most notably in the person of Alfred Wegener (Antonescu et al. 2019)." This situation changed after World War II when large research efforts to improve the observation, detection, understanding and forecasting of severe storms was ongoing in the United States during the second half of the twentieth century (e.g., Brooks et al. 2019, their sections 4 and 5). In contrast, research on European convective storms during this time was relatively scarce (e.g., Antonescu et al. 2016, 2017; Groenemeijer et al. 2017).

Also feeding into this lack of modern research on European convective storms was the lack of a pan-European database of severe weather reports (e.g., Doswell 2003, 148-149; Doswell 2005 , p. 700). It was not until researchers from numerous European countries came together at the European Conference on Tornadoes and Severe Storms in Toulouse in 2000 that the widespread threat of severe convective storms in Europe took on greater recognition and started a community-building effort (e.g., Dotzek et al. 2009; Groenemeijer et al. 2017, 2642-2643). This awakening led to the establishment of the European Severe Storms Laboratory (ESSL) and eventually a pan-European dataset for severe weather reports (Dotzek et al. 2009; Groenemeijer et al. 2017). The existence and continued growth of this database has since increased interest in severe convective storms in Europe, overcoming the self-fulfilling prophecy that Europe experiences few severe convective storms, as Doswell (2003, 148-149) argued. This increased interest has fueled research using the database for further mapping and understanding of such events. For example, recent publications have performed climatologies of severe convective storms in Europe (e.g., Dotzek and Forster 2011; Groenemeijer and Kühne 2014; Punge and Kunz 2016; Taszarek et al. 2018, 2019a). Recent focus has been predominantly on hailstorms (e.g., Punge and Kunz 2016; Punge et al. 2017; Púčik et al. 2019) due to their potential for large financial loss (e.g., Martius et al. 2015), as well as tornadoes (e.g., Groenemeijer and Kühne 2014; Antonescu et al. 2016, 2017). In contrast, severe convective windstorms have attracted less interest, especially on a pan-European scale.

Although numerous case studies of European long-lived convective windstorms, such as derechos, have been performed (e.g., Gatzen 2004; Punkka et al. 2006; López 2007; Hamid 2012; Celiński-Mysław and Matuszko 2014; Toll et al. 2015; Mathias et al. 2017; Taszarek et al. 2019b; Chmielewski et al. 2020), fewer climatologies of windstorms have been performed. The exceptions are Gatzen's (2013) study of warmseason severe wind events in Germany and Gatzen et al.'s (2020) climatology of derechos in Germany. The frequency of severe winds across Europe has only recently been mapped by Groenemeijer et al. (2017, their Fig. 3d) and Taszarek et al. (2019a, their Fig. 7), but there is potential for further analysis of these data. Thus, there is a large gap in the literature for climatological studies of severe convective winds on a panEuropean scale.

To predict windstorms, forecasters often assess the environments in which such storms form. Two recent studies have been performed in Europe on the environments favorable for severe convective windstorms. First, Púčik et al. (2015) showed, based on proximity soundings in central Europe, that severe convective winds generally occurred in environments with high convective available potential energy (CAPE) and moderate $0-6-\mathrm{km}$ wind shear. Another environment was alluded to in which CAPE was low but wind shear is very high, so-called high-shear-low-CAPE (HSLC) environments, which are more frequent in the cold season (as has been discussed in the United States by Fenelon 1998; Burke and Schultz 2004; van den Broeke et al. 2005; Sherburn and Parker 2014; Davis and Parker 2014; Sherburn et al. 2016; King et al. 2017). Second, Taszarek et al. (2017), again using proximity soundings, showed that severe convective wind events are most common in environments with high wind shear and steep low-level lapse rates. This study was performed using data in western and central Europe from March-September. Thus, these two studies are limited in space and time, meaning that a panEuropean perspective throughout the whole year has not been performed.

Radar signatures are used alongside environmental soundings to assess the likelihood of severe convective winds because different convective organizational modes identified on radar imagery (e.g., convective lines, cellular storms) can produce different types of severe weather phenomena. Namely, in the United States, bow echoes are recognized as the storm type usually associated with the production of severe convective wind events (e.g., Fujita 1978; Gallus et al. 2008). But, there is no reason to suspect that the frequency of different convective modes would be the same across the world. For example, cellular storms are the most common mode to produce tornadoes in the United States (e.g., Trapp et al. 2005; Smith et al. 2012), but quasi-linear convective systems (QLCSs) are the most common mode to produce tornadoes in the United Kingdom (e.g., Mulder and Schultz 2015; Clark and Smart 2016). To our knowledge, no pan-European analysis of convective storm mode from radar data has been conducted. Even within individual countries, such analysis is sparse (e.g., Mulder and Schultz 2015; Surowiecki and Taszarek 2020).

Thus, despite this growing interest in understanding severe convective windstorms across Europe, large gaps in our knowledge remain compared to the United States. The purpose of this article is to better understand severe convective winds in Europe using a three-stage approach. First, because pan-European climatologies of severe convective windstorms do not exist, and those climatologies that do are limited to parts of Europe and only parts of the annual cycle, a climatology of severe convective wind reports in Europe for all months of the year will be performed in section 2 . Second, the characteristics of the preconvective environment will be determined using proximity soundings in section 3 , shedding light on the conditions that may favor such windstorms. Third, convective organizational modes on radar data have not been classified across Europe, so radar analyses will be examined to assess the convective organization mode in section 4 . Finally, section 5 summarizes the results from this article. Lest this research be viewed as merely an academic exercise, Doswell (2015, p. 210) reminds us, "there must be a substantial effort to convince Europeans that they are not immune to severe convective weather hazards, since without public support, the weather community in Europe can do little 
to mitigate the threats posed by severe convective storms." Thus, as a secondary motive, this article aims to increase the exposure and the recognition of the threat posed by severe convective windstorms across Europe, as well as quantify areas of higher risk.

\section{Climatology}

A climatology of severe convective winds in Europe is produced using reports from the European Severe Weather Database (ESWD; Dotzek et al. 2009; Groenemeijer et al. 2017). The ESWD collects and provides detailed and qualitycontrolled information on severe convective storms across Europe. The ESWD relies on reports from the general public, newspapers, other media, and voluntary weather observers. The ESWD criterion for a severe wind gust is a measured wind gust greater than $25 \mathrm{~m} \mathrm{~s}^{-1}$ or damage inflicted by winds that were likely greater than $25 \mathrm{~m} \mathrm{~s}^{-1}$, so that is the minimum threshold used in the present study. Furthermore, to make it into the climatology for this present study, ESWD reports had to meet three criteria described further in section 2a: occur between 2009 and 2018, undergo a defined level of quality control, and arise from a convective storm.

\section{a. Building the climatology: Criteria and their evaluation}

The database became formally established in 2006, and we select the period 2009-18 to build the climatology. This most recent 10 -yr period at the time of the start of this research (early 2019) was a good compromise between too short a time period to construct a meaningful climatology and too long a time period to encompass a substantial variation in the size and construction of the dataset.

Reports submitted to the ESWD undergo quality control and are assigned one of the following levels: QC0, QC0+, QC1, or QC2 (Dotzek et al. 2009, p. 580). Quality-control level 0 (QC0) applies to any report received by the general public, which can then be upgraded to $\mathrm{QCO}+$ providing the plausibility of the report has been confirmed either by voluntary observers, weather services, and/or the ESSL. QC1 signifies that the report has been confirmed by a reliable source, and QC2 signifies that the report has been the subject of a scientific case study. For the present study, we chose only data that have been classified $\mathrm{QC0}+$ or higher.

Wind reports that are quality checked and controlled by the ESSL may be labeled with a parameter value of "nonconvective," "partly convective," or "convective." Reports were assigned to a category using auxiliary tools such as radar and satellite data. Such a task is potentially challenging because of the difficulty of classification during cold-season convection with strong synoptic-scale forcing (e.g., van den Broeke et al. 2005). This classification was discontinued starting in 2019, in part due to these difficulties. At first glance, choosing only reports labeled "convective" would seem prudent, given the intent of this article. Nevertheless, to test the sensitivity to this decision, we conducted an analysis of the data, which revealed the challenges in defining a climatology of severe convective winds. Specifically, we assessed the number of days with severe wind reports from the ESWD with QC0+ or better (confirmed plausibility) between 2009 and 2018 using three different approaches.

The first approach shows all wind reports, regardless of convective classification (Fig. 1a). The second approach shows the subset of wind reports labeled "convective" within the ESWD (Fig. 1c). This approach is similar to that of Taszarek et al. (2017) who excluded reports labeled as "nonconvective" by the ESWD in order to select just convective winds. The third approach identifies severe convective winds in a different independent way, determining the subset of all severe wind reports associated with lightning within a $0.25^{\circ}$ latitude $\times$ $0.25^{\circ}$ longitude grid box and within $1 \mathrm{~h}$ of the severe wind report time (Fig. 1e). Lightning data were provided by the Met Office, which uses an arrival time difference network (ATDnet) to detect lighting strokes (Met Office 2020). Taszarek et al. (2019a) used a similar approach to distinguish between convective and nonconvective winds. However, we caution that severe winds can occur in the absence of cloud-to-ground lighting strikes but still with rain rates appropriate for convective storms (e.g., van den Broeke et al. 2005). What this caution means in practice is that, in an ingredients-based forecasting approach (e.g., Doswell et al. 1996), the ingredients for lightning (articulated in section 2 of van den Broeke et al. 2005) are different from the ingredients for severe convective winds. There may be some overlap, but the ingredients are different. The resulting climatologies based on these three approaches are presented as a contoured field within $1^{\circ}$ latitude $\times 1^{\circ}$ longitude grid boxes (Fig. 1).

Between 2009 and 2018, there were 50816 reports of severe winds (Fig. 1a), 10233 reports labeled convective (Fig. 1c), and 18526 reports of severe winds associated with lightning (Fig. 1e). All European countries experienced severe winds or a severe wind associated with lightning (Figs. 1a,e), and all European countries except Iceland had at least one report of a severe convective wind (Fig. 1c), highlighting the threat severe convective winds pose Europe-wide. The majority of reports occurred over continental Europe, although there were also reports on islands in the Mediterranean Sea (e.g., Corsica, Crete). The spatial distribution of the reports shows similar patterns in general, with the highest report density generally across Central Europe (Figs. 1a,c,e). Whereas all severe wind reports were most frequent in northern Germany and the Mediterranean coast of France (Fig. 1a), severe wind reports labeled as "convective" were most frequent in Poland, the Czech Republic, and Austria (Fig. 1c), and severe wind reports associated with lightning were most frequent in Germany, Poland, the Czech Republic, and Austria (Fig. 1e). Some caution is required as the wind reports and their classification as "convective" rely largely on human observation. Sharp gradients across some country borders occur between areas with little reporting and areas with more aggressive reporting. For example, since 2010, Skywarn Poland has been active in collecting reports, quality controlling them, and inserting them into the ESWD (Taszarek and Brooks 2015, 703, 714). Thus, Poland has a higher number of reports labeled "convective" compared to surrounding countries (Fig. 1c). 

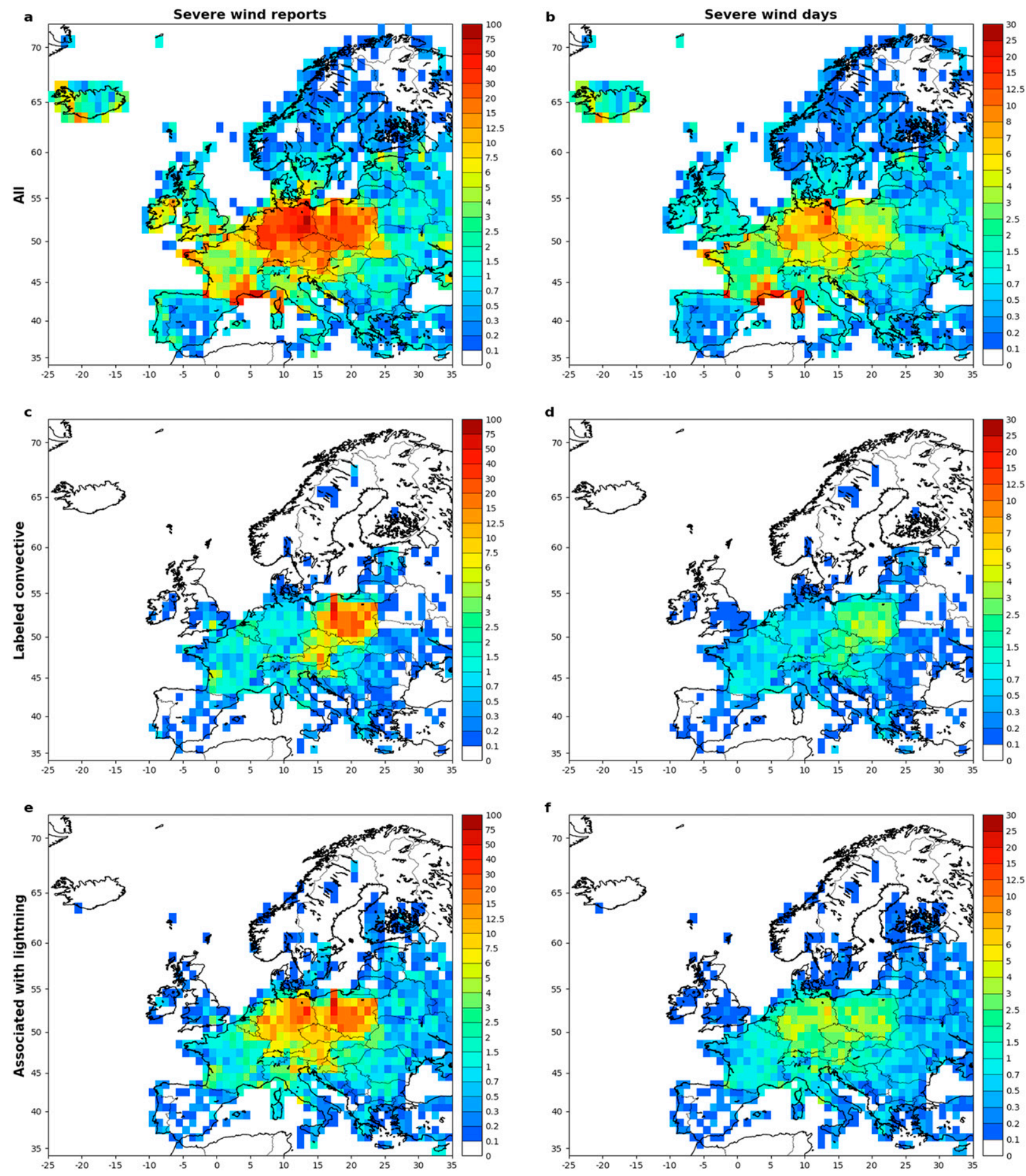

FIG. 1. Number of severe wind reports per year in $1^{\circ} \times 1^{\circ}$ latitude-longitude grid boxes between 2009 and 2018: (a) all reports, (c) reports labeled convective by ESWD, and (e) reports associated with lightning. Number of severe wind days per year in $1^{\circ} \times$ $1^{\circ}$ latitude-longitude grid boxes between 2009 and 2018: (b) all severe wind days, (d) days with reports labeled convective by ESWD, and (f) days with reports associated with lightning. A wind day is a day where at least one report was recorded within a given grid box.

Figure 1a is very similar to the one previously published by Groenemeijer et al. (2017, their Fig. 3d) showing a maximum in Germany and secondary maxima in Poland and southern France. Any differences are because our Fig. 1a contains all wind reports between 2009 and 2018 and their figure contains all wind reports from the beginning of the ESWD to November 2016. This comparison indicates the need for continued improvement in reporting practices to maximize report collection. 

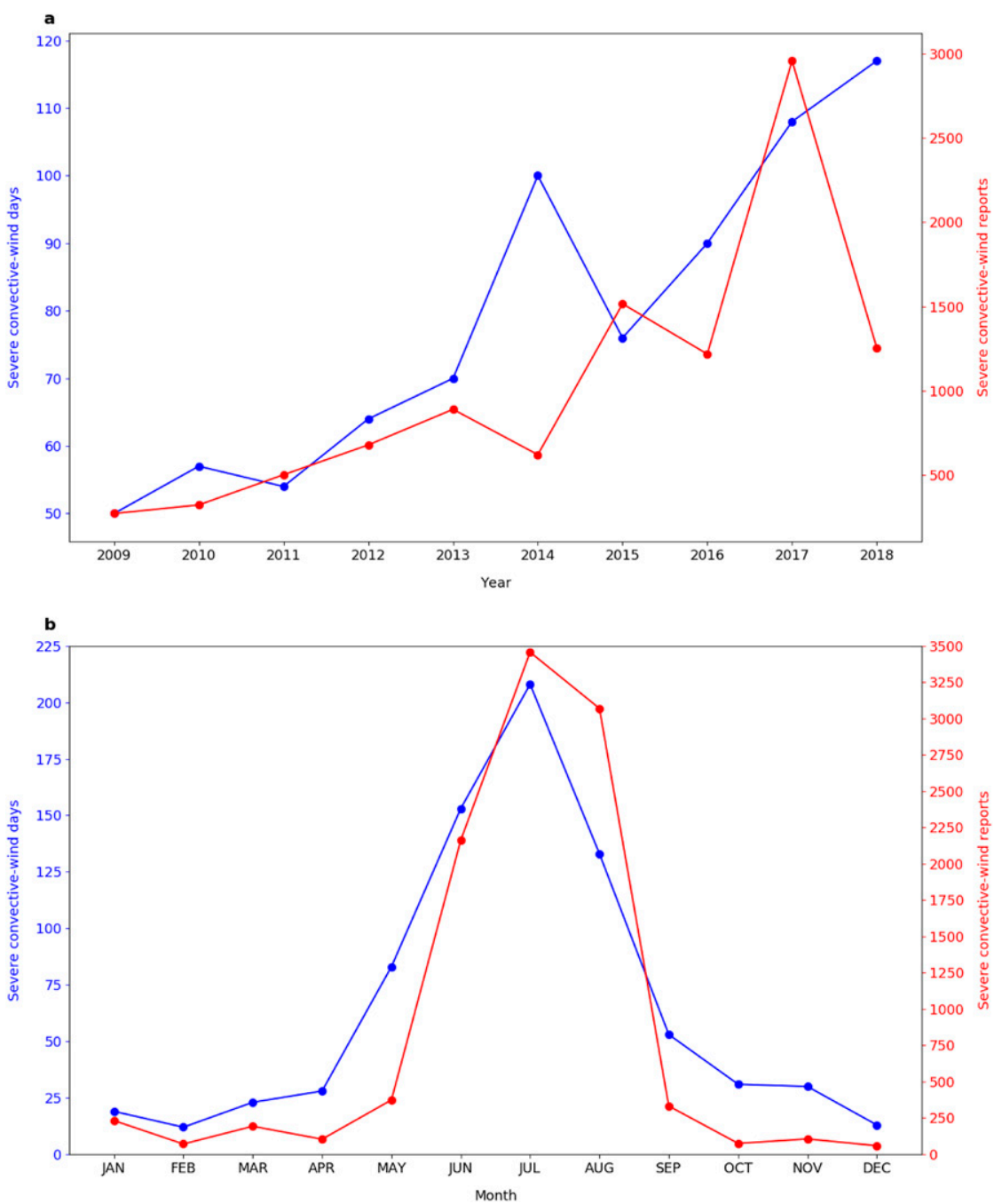

FIG. 2. The number of severe convective wind reports (red lines) and days (blue lines) between 2009 and 2018 by (a) year and (b) month.

Another issue affecting these maps is that typically there were multiple reports associated with each event, with some events during some long-lasting storms manifesting as clusters of reports on the map. In particular, a heavily populated line of reports occurred over northwest Poland in association with a derecho on 11 August 2017 (Taszarek et al. 2019b). This line of reports can be located on Figs. 1c and 1e, and to a lesser extent on Fig. 1a. During the day of the derecho, 1163 reports were confirmed in Poland alone, which is $40 \%$ of the total number of reports across Europe during all of 2017.

To avoid this kind of reporting bias, we calculated the number of days (per year) with severe convective wind reports within $1^{\circ}$ latitude $\times 1^{\circ}$ longitude grid boxes (Figs. 1b,d,f). Comparing the maps of the number of reports to the maps of the number of days shows a number of similarities (cf. Figs. 1a,c,e and 1b,d,f). However, comparing Figs. 1d and 1f shows one critical difference. Germany had fewer severe wind days labeled "convective" than those associated with lightning. With the exception of Germany,
Figs. 1d and 1f agree fairly well. Central Europe had the highest frequency of severe convective wind days with $2-5$ days $\mathrm{yr}^{-1}$, which compares extremely well to $2-6$ days $\mathrm{yr}^{-1}$ in Taszarek et al. (2019a, their Fig. 7).

Based on our exploration of the ESWD dataset, we believe that the manual assessment by ESWD of a "convective" severe wind report provides the best approach for the present study. Although there will be some biases in the distribution of severe convective wind reports due to reporting biases, this is more than offset by confidence that the storms are not associated with large-scale synoptic windstorms. Such confidence will be especially important in sections 3 and 4, where we consider preconvective environments and convective mode of severe convective storms. Thus, we choose to proceed with severe convective wind reports that met the following three criteria: occur between 2009 and 2018, achieve a quality-control level of $\mathrm{QCO}+$ or higher, and defined as "convective" by the ESWD (Fig. 1c). 


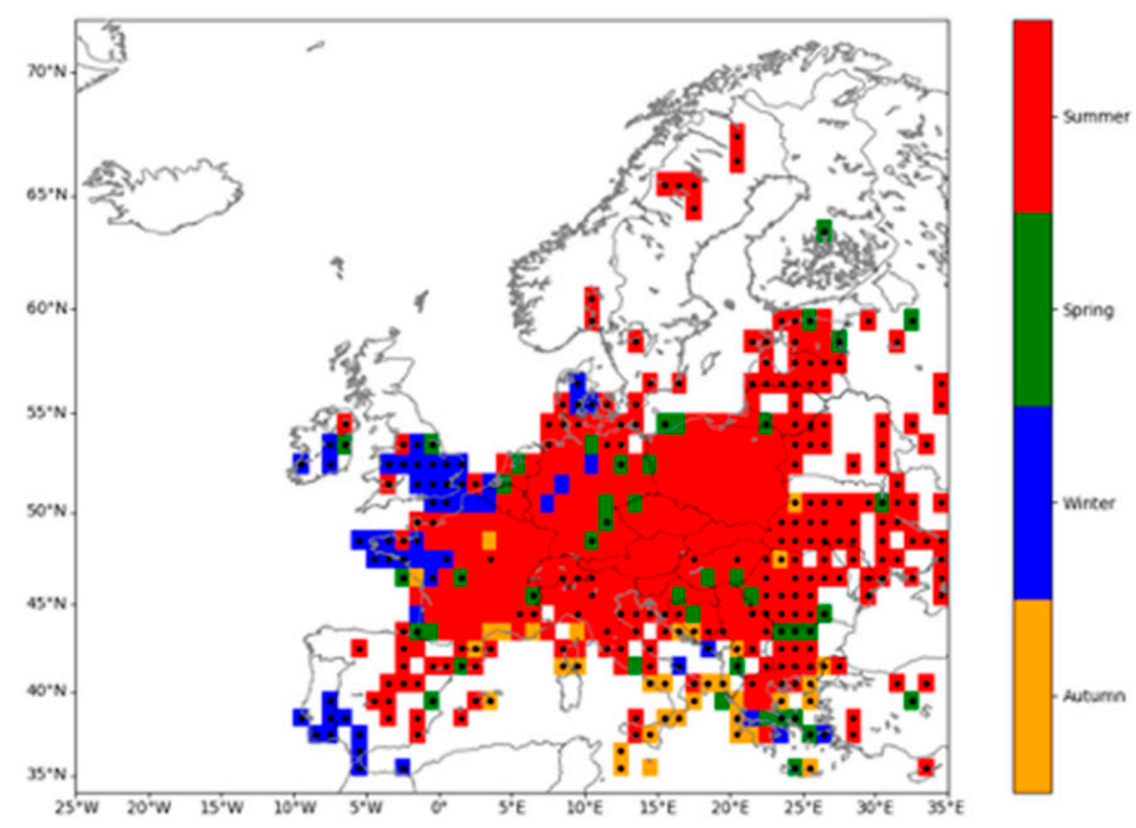

FIG. 3. Peak season of severe convective wind days in $1^{\circ} \times 1^{\circ}$ grid boxes between 2009 and 2018: autumn (SON), winter (DJF), spring (MAM), and summer (JJA). Modal value is used. Dots indicate grid boxes that have three or fewer wind days.

\section{b. Severe convective winds by year}

The number of reported severe convective wind days (i.e., a day when at least one severe convective wind report was recorded anywhere in Europe) has gradually increased from 50 days $\mathrm{yr}^{-1}$ in 2009 to a maximum of 117 days in 2018 (Fig. 2a). An increasing trend is also apparent in the number of reports: 272 reports in 2009 to 1254 reports in 2018, consistent with the trend apparent in Groenemeijer et al. (2017, their Fig. 5). Such an increase likely represents an underreporting of events, as noted by Groenemeijer and Kühne (2014) for European tornadoes in the ESWD. In December 2015, the ESSL also introduced European Weather Observer (EWOB), a smartphone app to collect reports from citizen scientists, further making it easier for the public to supply reports (e.g., Krennert et al. 2018). The increasing trends are likely to be primarily due to increased awareness of the database and increased reporting methods and efficiency of collections (e.g., increased social media and smartphone use). In addition, a large spike in reports occurred in 2017, which can be attributed to the aforementioned Poland derecho that received 1163 reports on a single day. As a consequence, these changes in reporting practices and interannual variability in events make determining any real meteorological signal from this time series challenging.

\section{c. Severe convective winds by season}

Seasonal cycles are affected less by annual changes in reporting. The annual cycles of severe convective wind reports and days both possess a well-marked summer peak (Fig. 2b). In fact, $85 \%$ of all reports and $63 \%$ of all days occurred during June-August. Severe convective winds were reported on $54 \%$ of summer days, implying that there would be a 0.54 probability that a severe convective wind event will occur somewhere in Europe on a given day in the summer. Fewer reports and days of convective winds occurred during the cold season, with only $4 \%$ of all reports and $6 \%$ of all days occurring between DecemberFebruary.

Although the most frequent reporting of severe convective wind events is during the summer (Fig. 2b), the peak season for severe convective storms, as well as the type of severe weather they produce, can vary by location (Taszarek et al. 2019a). Figure 3 shows the peak season of wind days within the $1^{\circ}$ latitude $\times 1^{\circ}$ longitude grid boxes. A limitation to this type of analysis is that with low reporting in some regions, some grid boxes are referring to the season of a single day with an event rather than the most frequent reporting season; to identify these boxes, dots are used in Fig. 3 to indicate boxes with three or fewer days. Most grid boxes (74\%) experienced the peak number of days in the summer. However, some grid boxes near the Mediterranean Sea had peak occurrence during autumn. A winter maximum occurred across the extreme west of Europe: the United Kingdom, Ireland, northwest France, and the west coast of Spain and Portugal. These windstorms were likely not associated with lightning, as indicated by Taszarek et al. (2019a, their Fig. 4).

\section{d. Severe convective winds by hour}

The diurnal cycle of severe convective wind events (Fig. 4a) shows similar attributes to the diurnal cycle of convection (e.g., Fig. 12a in Morel and Senesi 2002). Indeed, over half of all events occurred between 1300 and 1900 local solar time (calculated using the method at https://www.pveducation.org/pvcdrom/properties-of-sunlight/ solar-time), with a peak number of events between 1500 and 1800 local solar time. No additional maxima were present during 

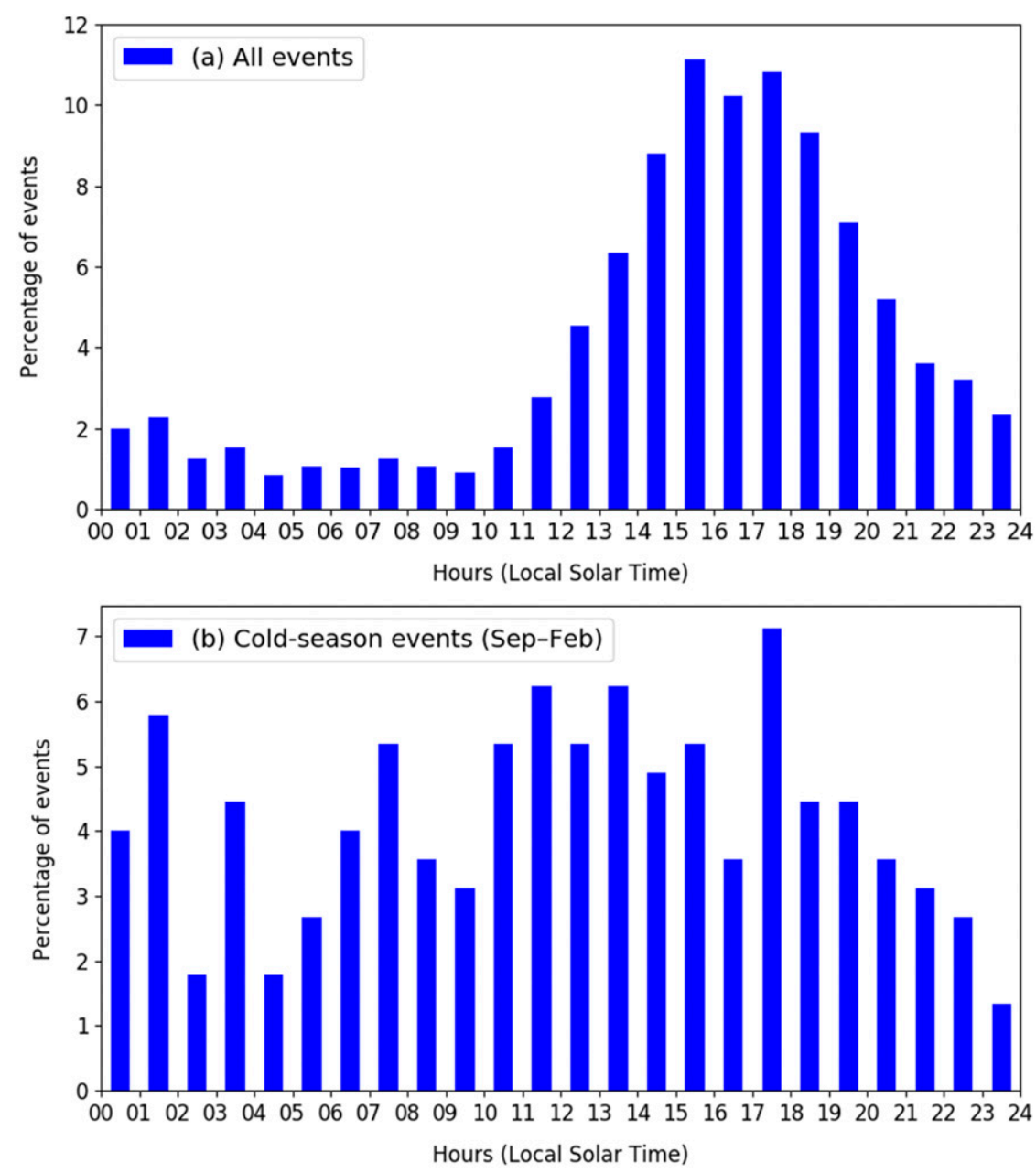

FIG. 4. Local solar time distribution of severe convective wind events between 2009 and 2018 . The time refers to events falling within that hour (a) for all events and (b) September, October, November, December, January, and February events.

the nighttime, although some reporting bias was likely as people are generally outside more during the day to witness events. During the cold season of September-February (Fig. 4b), there was a reduced diurnal cycle with no clear maximum between 1300 and 1900 local solar time (cf. Figs. 4a,b). The difference between the two panels is particularly marked between 0000 and 1200 UTC, when $48 \%$ of cold season events occurred in this time period compared to only $17 \%$ of all events. A similar diurnal cycle to Fig. 4a was present for spring and summer events (not shown).

\section{Preconvective environments}

Given severe convective wind reports from the ESWD, the preconvective environment can be inferred using atmospheric profiles, or soundings. Proximity soundings allow us to determine what conditions are most likely to lead to damaging winds (as opposed to the strongest storms more generally), as well as whether these conditions vary by season. We obtain radiosonde data from the University of Wyoming website. Proximity criteria need to be specified. Past studies have used a range of spatial and temporal criteria (e.g., Table 1 in Potvin et al. 2010): for example, $400 \mathrm{~km}$ and from $6 \mathrm{~h}$ before to $3 \mathrm{~h}$ after radiosonde launch (Rasmussen and Blanchard 1998), $200 \mathrm{~km}$ and $3 \mathrm{~h}$ after radiosonde launch (Cohen et al. 2007), $150 \mathrm{~km}$ and $3 \mathrm{~h}$ after (Puičik et al. 2015), and $125 \mathrm{~km}$ and from $2 \mathrm{~h}$ prior to $4 \mathrm{~h}$ after (Taszarek et al. 2017). The proximity criteria that best represent the storm environment are not easy to determine, as Potvin et al. (2010) showed for proximity soundings for significant tornadoes in the United States. Ideally, the environment should represent the conditions in which the severe convective storm formed, but storms often form in environments characterized by spatial and temporal inhomogeneity (e.g., Brooks et al. 1994). The criteria chosen also needed to consider the number of soundings that would result. Liberal criteria would allow more soundings to be identified at the expense of less representative environments. A relatively strict criterion of $100 \mathrm{~km}$ was used in this study for the spatial criterion to minimize unrepresentative environments. Radiosondes were only included in the analysis if they were launched between $30 \mathrm{~min}$ and $3 \mathrm{~h}$ before the report time. A maximum of $3 \mathrm{~h}$ is a standard threshold used in past literature and 


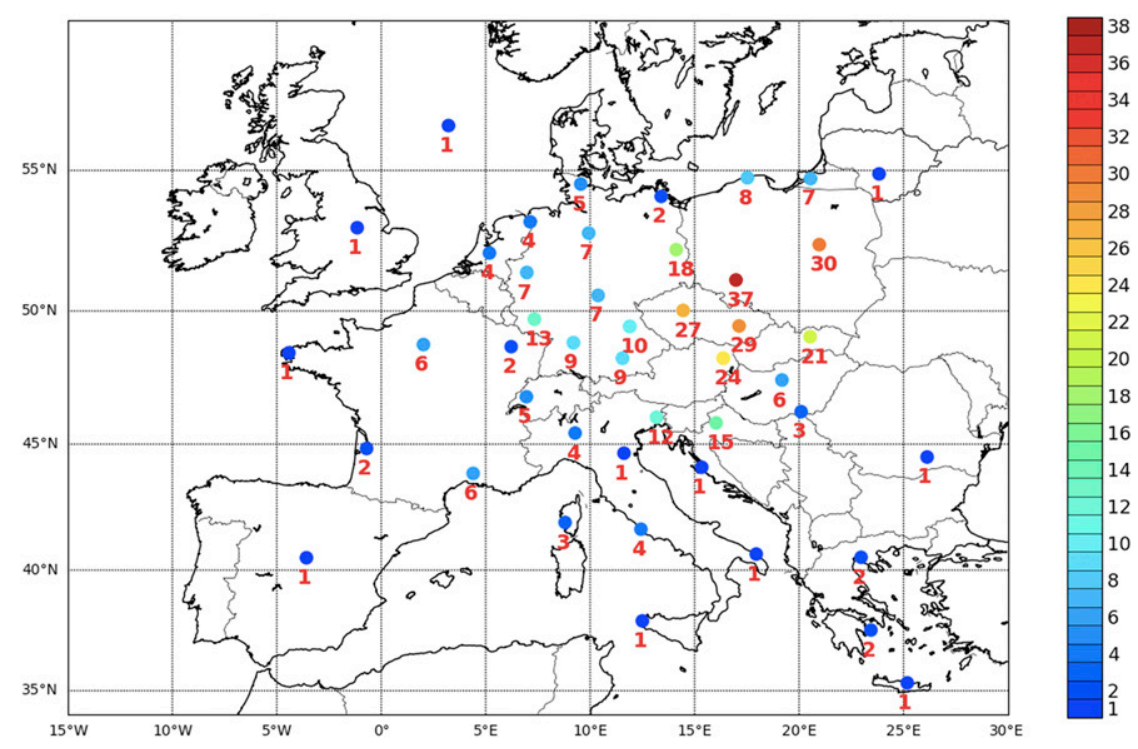

FIG. 5. Number of radiosondes per station included in the present analysis (total of 361 radiosondes). Station location is color coded and labeled by count.

avoids too many unrepresentative environments being incorporated in the analysis. Depending on the source of the report, the exact report time cannot always be identified, thus a time error is associated with the report in the ESWD. Therefore, a minimum of $30 \mathrm{~min}$ was used to consider time error on reports. The aim was to avoid including radiosondes that were launched at the time of the event and thus did not profile the prestorm environment. Also, incomplete soundings or soundings with fewer than 15 vertical levels between the surface and $10 \mathrm{~km}$ were omitted.

By applying the $0.5-3-\mathrm{h}$ and $100-\mathrm{km}$ criteria, 361 proximity radiosondes were found in the University of Wyoming archive across 45 European stations between 2006 and 2018 (Fig. 5). In this section, we also look at cases in 2006-08 to increase the size of the dataset of proximity soundings. The majority of proximity soundings occur across Central Europe, which, as previously highlighted in section 2 , received the highest number of reported wind days within the $10-y r$ climatological period. Additional countries and regions are represented such as 23 soundings in Italy, 20 in France, 15 in Croatia, and 5 in Greece.

After identifying soundings using these criteria, nine convective parameters were calculated from the soundings. The parameters were selected due to their common application in previously published research on convective storms and severe convective winds (e.g., Brooks et al. 1994; Tudurí and Ramis 1997; Evans and Doswell 2001; Doswell and Schultz 2006; Kaltenböck et al. 2009; Púčik et al. 2015; Taszarek et al. 2017, 2018). Downdrafts can be accelerated in environments due to negatively buoyant air associated with subcloud evaporation in low-level dry air, so average relative humidity was analyzed over two different layers: surface-850 hPa (AVRHS-850) and 700-500 hPa (AVRH700-500). Lapse rates were analyzed in the boundary layer and the midlevels as steep lapse rates can enable the downdraft to maintain negative buoyancy as it starts to warm upon descent: $0-1 \mathrm{~km}$ above ground level (AGL) lapse rate (LRS-1KM) and 700-500-hPa lapse rate (LR700-500).
CAPE is a typical storm parameter that is widely used in severe storm forecasting. Although CAPE (defined here as 0-500-m mixed-layer CAPE) is not directly linked to the downdraft (rather the updraft), in high-CAPE environments larger amounts of hydrometeors can be suspended in the updraft. Once the hydrometeors are released from the updraft a stronger downdraft can result through evaporative cooling. Indeed, Weisman and Klemp (1982) found that greater instability (CAPE) increased downdraft strength. Downdraft convective available potential energy (DCAPE) can be used to estimate downdraft or cold-pool strength (Evans and Doswell 2001; Kuchera and Parker 2006), both of which can cause damaging winds. DCAPE was calculated by first locating the level of free sink (LFS), which is approximated as the minimum equivalent potential temperature $\theta_{e}$ in the profile between the surface and $400 \mathrm{hPa}$. Then, the parcel is followed down to the surface from the LFC along the moist adiabat. Vertical wind shear is another severe storm parameter as storm updrafts are tilted in high-shear environments, which can lead to longerlasting and better-organized storms, and low-level shear can provide vorticity for rotating storms (e.g., Brooks 2009; Potvin et al. 2010; Púčik et al. 2015). Thus, we calculated 0-6 km above ground level (AGL) bulk wind shear (BSS-6KM) and 0-1 km AGL bulk wind shear (BSS-1KM). Surface temperature (TSURF) was also added to investigate whether environments were linked to a particular surface temperature.

An initial investigation into these data showed that most of the nine parameters had large spreads in each variable (Pacey 2020), indicating that there was likely to be more than one environment in which severe convective winds occur or that our proximity criteria were not strict enough in sampling unrepresentative environments. We identify these environments using an unsupervised machine-learning technique called $k$-means clustering (e.g., section 14.3.1 in Wilks 2006). To our knowledge, $k$-means clustering has not been performed 
on European severe convective wind proximity soundings, although it has been applied to proximity soundings in Europe (Tudurí and Ramis 1997). The $k$-means clustering algorithm allows for classification of entities (in this case, severe convective wind environments) defined by a set of variables (in this case, the nine convective storm parameters). To cluster these data, first, all nine parameters were standardized so that they were dimensionless. Then, each sounding was associated to a cluster so that the variability of parameters was minimum within the cluster, but was maximum between other clusters. The number of clusters must be chosen before running the $k$ means clustering algorithm. Results for two, three, four, and five clusters were tested in Pacey (2020); we chose two clusters to best represent the clustering of the dataset. The details of the clustering method and the justification for the choice of two clusters are discussed in Pacey (2020, his chapter 3). Cluster 1 (which we call Type 1) accounted for $283(78 \%$ ) of the 361 soundings, and cluster 2 (which we call Type 2) accounted for 78 soundings (22\%).

Using the unstandardized dimensional values of the convective storm parameters, box-and-whisker plots for each cluster are presented in Fig. 6. The lack of overlap between the boxplots for all comparisons except LR700-500 suggests that these populations are statistically distinct at the $95 \%$ level, a result confirmed by calculation of $p$ values for a two-sided Student's $t$ test (not shown). The parameters CAPE, DCAPE, TSURF, LRS-850, AVRH850, and BSS-1KM show the best separations (Fig. 6). Type 1 had higher magnitudes of CAPE, DCAPE, TSURF and LRS-1KM than Type 2, whereas Type 2 had higher magnitudes of AVRHS-850, BSS-1KM, and BSS$6 \mathrm{KM}$ than Type 1 . The mean of LR700-500 was about the same for both clusters. Thus, Type 1 and Type 2 are generally similar to soundings that are classified as low-shear-high-CAPE (LSHC) and high-shear-low-CAPE (HSLC), respectively. Despite good separation of CAPE between clusters, some lowCAPE environments remained in the Type- 1 cluster, although only $12 \%$ of radiosondes in this cluster had CAPE less than $100 \mathrm{~J} \mathrm{~kg}^{-1}$ as opposed to $72 \%$ of radiosondes in the Type- 2 cluster. We speculate that the radiosondes with low-CAPE environments in Type 1 did not capture the true storm environment in these events (especially for the zero-CAPE environments). DCAPE values in the Type- 1 cluster were moderate with the interquartile range (IQR) between 700 and $1150 \mathrm{~J} \mathrm{~kg}^{-1}$ compared to a more modest range of 50 $300 \mathrm{~J} \mathrm{~kg}^{-1}$ for the Type- 2 cluster. Similar results were found by Gatzen et al. (2020) for derechos in Germany: two clusters that were comparable with Type 1 and Type 2 . These results are also comparable to environments for bow echoes over central Europe by Celiński-Mysław et al. (2020).

The two environments can be summarized in Fig. 7. The top-left corner of the figure, which represents high shear with little to no CAPE, is dominated by cases with lower temperatures (generally less than $10^{\circ} \mathrm{C}$ ). In contrast, higher CAPE occurred with lower values of shear, but temperatures were generally higher (generally higher than $25^{\circ} \mathrm{C}$ ). There were some outliers, which could be explained by the fact that even the choice of a conservative proximity criteria was not enough to eliminate soundings that did not represent the storm environment well. Second, it is not obvious that a certain threshold of CAPE or shear exists that alone would serve as a good predictive tool for severe convective winds.

\section{Convective mode}

The term convective organizational mode, or convective mode, describes the organizational morphology of convective cells or groups of cells, usually determined from radar data (e.g., Gallus et al. 2008; chapters 8 and 9 of Markowski and Richardson 2010). The likelihood of a severe convective storm producing certain convective hazards such as hail, wind, and tornadoes is different depending on the convective mode (Smith et al. 2012). The convective mode of severe convective wind events in Europe has received little attention compared to efforts in the United States (e.g., Klimowski et al. 2003; Gallus et al. 2008; Duda and Gallus 2010; Smith et al. 2012). Although Gatzen (2013) classified warm-season severe wind events in Germany, Celiński-Mysław and Palarz (2017) classified warm-season bow echoes in Poland, and Surowiecki and Taszarek (2020) classified mesoscale convective systems and derechos in Poland, a climatology of severe convective wind modes has not been performed on a pan-European scale. This section performs such classifications across Europe and puts these in the context of previous literature.

To obtain radar data across Europe for classification, we use the Operational Program for Exchange of Weather Radar Information (OPERA; Huuskonen et al. 2014; Saltikoff et al. 2019). OPERA has facilitated the development of a pan-Europe radar network consisting of 200 radars in 30 countries. OPERA data consists of 96 daily radar mosaics at 15 -min intervals and at 2-km horizontal grid spacing. The availability of this dataset in 30 European countries presents a unique opportunity to analyze severe convective windstorm modes on a pan-European scale. Radar data were available between 2013 and the present. Following the results from section 3, all events in radiosonde proximity were classified, limiting the resultant number of storms to be analyzed and allowing the storm environment to be inferred. Of the 361 proximity soundings between 2006 and 2018 in section 3, 245 occurred between 2013 and 2018. A total of 15 events were removed as radar data were either not available or clear precipitation was not visible. If reports were in proximity to more than one radiosonde and the storm morphology was the same, these reports were considered only as one event; 45 events were not included as a result. The remaining 185 radiosondes (Fig. 8) were classified based on the associated convective mode determined from radar imagery.

Different classification schemes have been used in the previous literature depending on the aims and objectives of the study. For example, some studies sought only to divide storms into a small number of categories, such as quasi-linear convective systems (QLCSs), supercells, and other (Trapp et al. 2005) or simply bow echoes (e.g., Burke and Schultz 2004). Later, Smith et al. (2012) used a more detailed scheme where QLCSs were divided into lines or bow echoes and supercells were divided into discrete cell, cell in cluster, or cell in line. Parker and Johnson (2000) proposed a new scheme for mesoscale convective systems (MCSs) based on the relative 

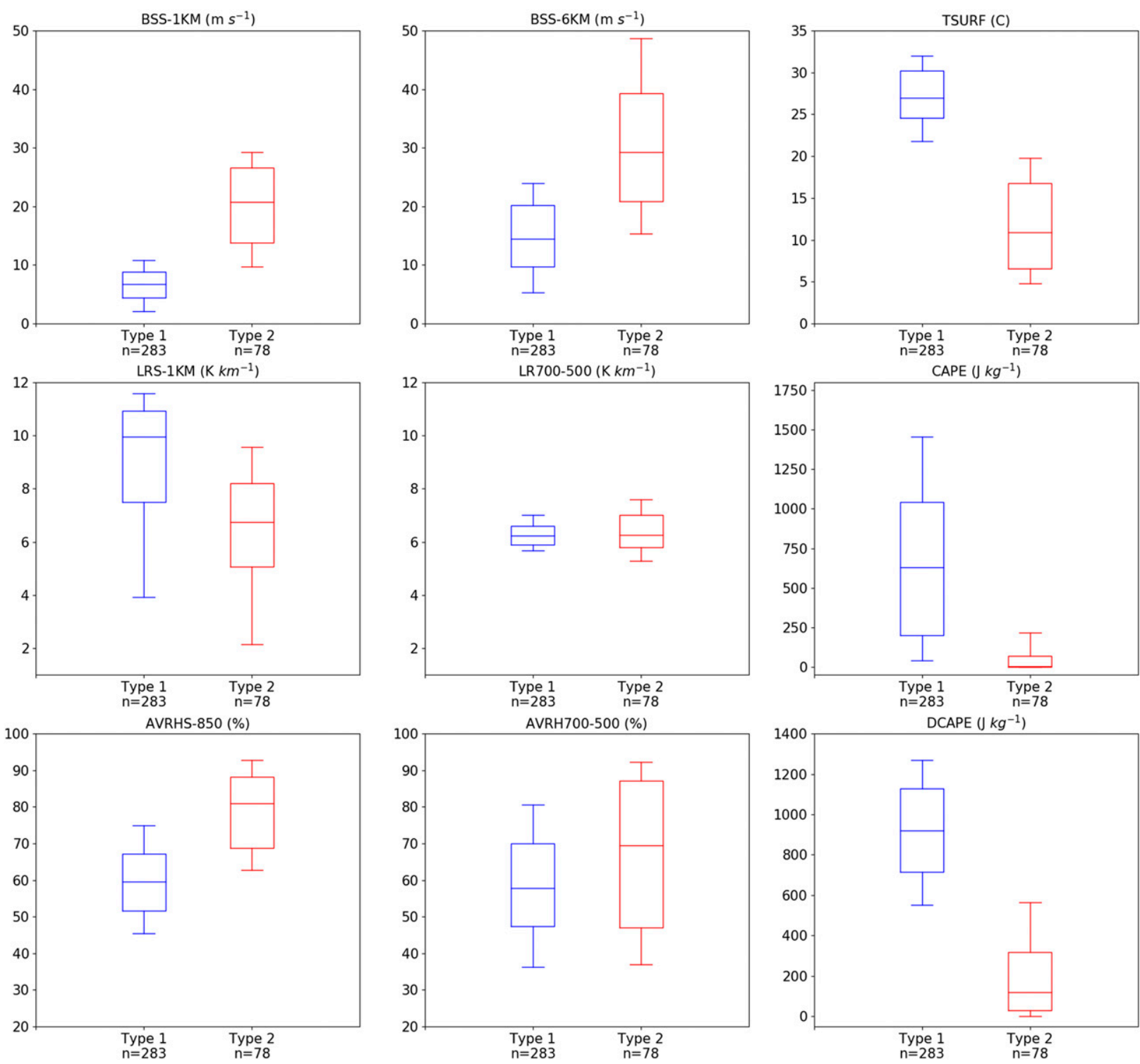

FIG. 6. Box-and-whisker plots for nine convective-storm indices by cluster. The median is represented as a horizontal line, boxes represent the 25 th- 75 th percentile values, and whiskers represent the 10 th and 90 th percentile values. Type- 1 and Type- 2 clusters consist of 283 and 78 radiosondes, respectively.

locations of the convective and stratiform precipitation regions from radar imagery: leading stratiform (LS), parallel stratiform (PS), and trailing stratiform (TS). Parker and Johnson's (2000) scheme was subsequently used in a classification scheme by Gallus et al. (2008), which classified storms into nine categories (Fig. 9). The scheme possesses five linear modes, of which are the three from Parker and Johnson (2000), as well as bow echo (BE) and no stratiform (NS); three cellular modes, which are isolated cell (IC), cluster of cells (CC), and broken line (BL); and one nonlinear mode (NL). The Gallus et al. (2008) scheme was selected for this study as it demonstrates nine storm morphologies that can be easily identified within the capabilities of the OPERA dataset. The OPERA dataset does not have readily available a
Doppler-velocity product, so supercells could not have been identified.

Even with a suitable classification scheme, a number of challenges can still arise. For example, the scheme is manual, and different users may discriminate between clusters and lines differently. Furthermore, convective storms can transition mode throughout their evolution, and numerous modes can be present at one time. In the present study, manual inspection was used to determine the mode that produced the most reports (within radiosonde proximity), which was then used as the classified mode.

For the 185 severe convective wind events between 2013 and 2018, the most frequent modes were isolated cells (33\%), followed by clusters of cells (21\%) (Fig. 10). In total, cells 


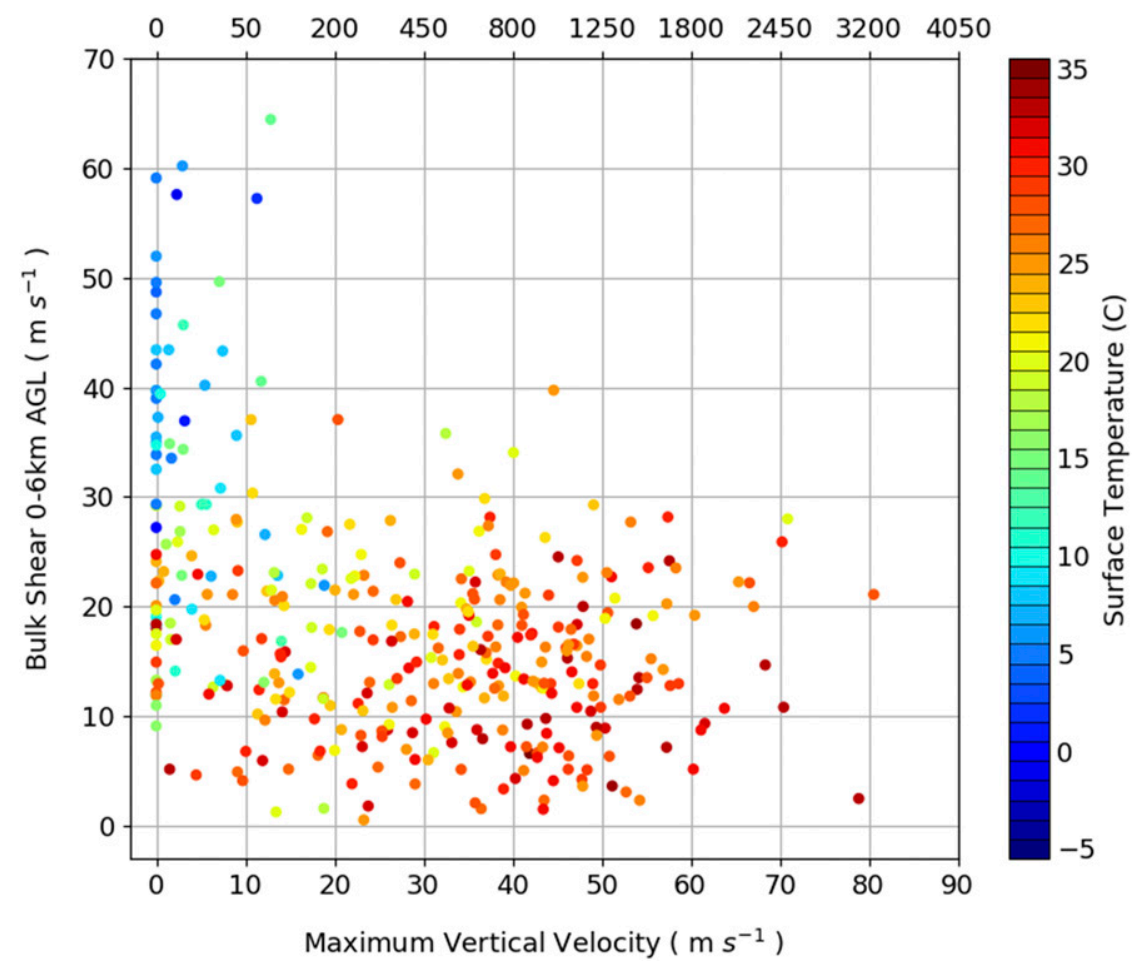

FIG. 7. Scatterplot of $0-6-\mathrm{km}$ bulk shear (BSS-6KM) vs maximum vertical velocity and CAPE for all soundings, with each point colored by the surface temperature. Maximum vertical velocity is calculated as $\sqrt{2 \mathrm{CAPE}}$.

accounted for $55 \%$ of events (IC, CC, and $0.5 \% \mathrm{BL}$ ). Linear modes accounted for $33 \%$ of events $(10.8 \% \mathrm{NS}, 9.7 \% \mathrm{BE}$, $8.6 \%$ TS, $2.7 \%$ LS, and $1.6 \%$ PS). Nonlinear modes (NL) accounted for $12 \%$ of events. These percentages can be compared to a 7-yr dataset for the United States: $47 \%$ for disorganized (i.e., cells and clusters that are neither QLCSs nor supercells) gusts, $42 \%$ for QLCS gusts, and $11 \%$ for supercell gusts (Smith et al. 2013), although these numbers are sometimes difficult to compare to those in Europe because of the different classification scheme. These numbers can also be compared to a 5-yr dataset for China: $35.4 \%$ for cluster of cells, $18.4 \%$ for squall lines, $17.8 \%$ for nonlinear-shaped systems,

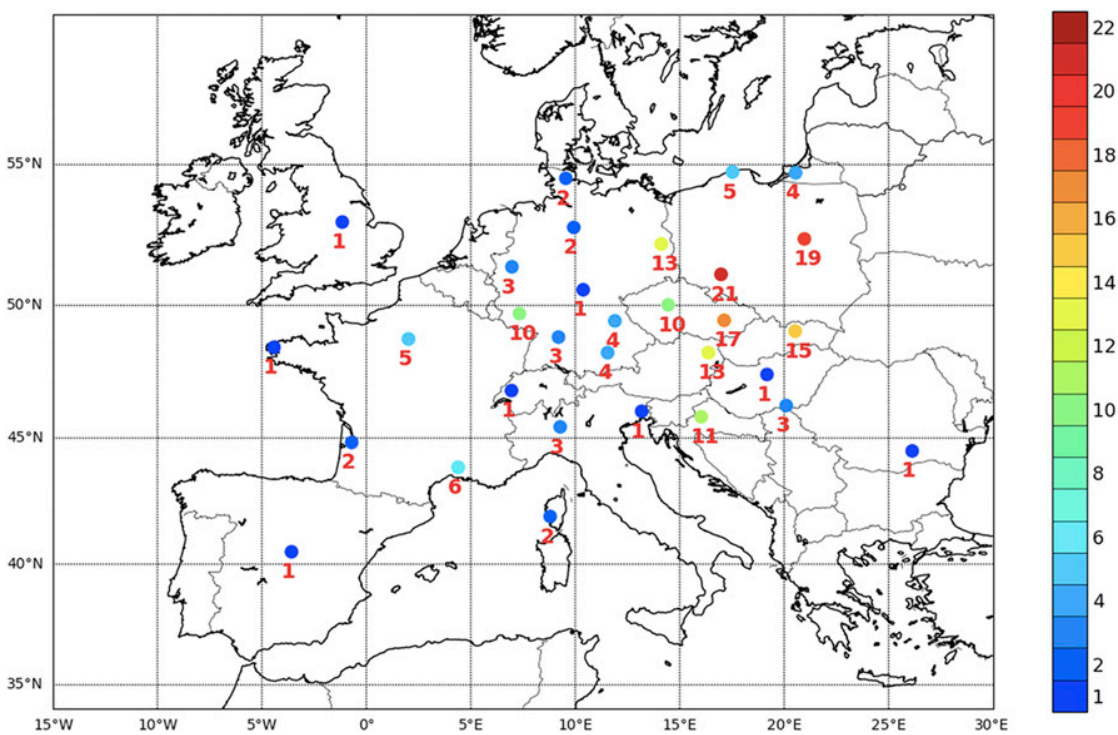

FIG. 8. Location of proximity soundings between 2013 and 2018 from 185 events classified by their convective mode. 


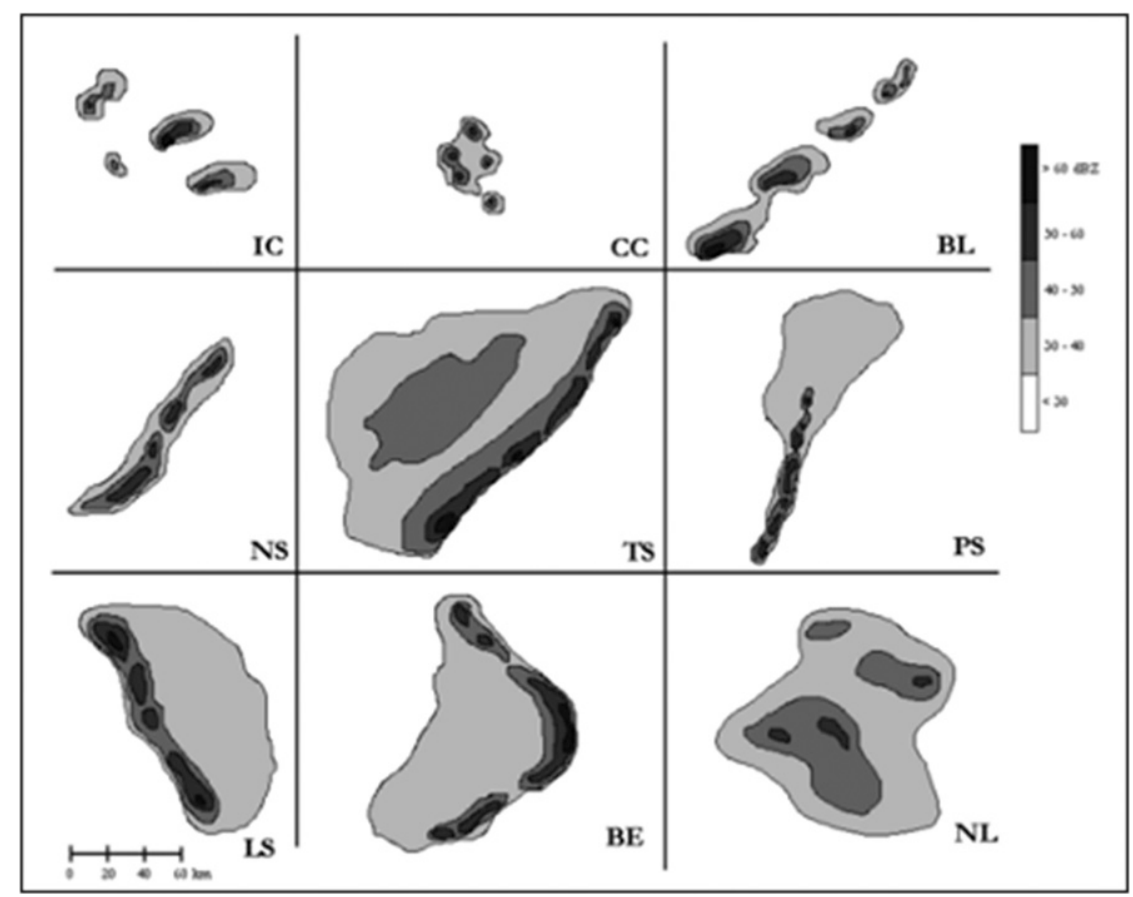

FIG. 9. Convective-mode classification scheme from Gallus et al. (2008, their Fig. 2). The abbreviations are as follows: isolated cell (IC), cluster of cells (CC), broken line (BL), no stratiform (NS), trailing stratiform (TS), parallel stratiform (PS), leading stratiform (LS), bow echo (BE), and nonlinear (NL).

$11.6 \%$ for broken lines, $1.2 \%$ for individual cells, and $0.5 \%$ for bow echoes (Yang and Sun 2018), or 36.6\% for cells and $30.5 \%$ for lines. The percentage of severe wind-producing cells in Europe (55\%) is higher than that in China $(36.6 \%)$, but comparable to that in the United States $(58 \%$, sum of disorganized and supercells). The percentage of severe wind-producing linear systems in Europe (33\%) is similar to that in China (30.5\%), but both are less than that in the United States $(42 \%)$. For mesoscale convective systems in general over Poland, $58 \%$ are broken line, $25 \%$ are areal/cluster, and $17 \%$ are quasi-linear convective systems (Surowiecki and Taszarek 2020).

Figure 11 also splits the dataset into the 152 Type- 1 and 33 Type- 2 events to assess if there is a difference in storm morphology depending on the environment. Cells were more frequent in the Type- 1 cluster accounting for $58.5 \%$ of events, followed by linear modes $(29 \%)$ and the nonlinear mode (12.5\%). However, in Type-2 environments, linear systems were the most frequent mode and accounted for $55 \%$ of events, followed by cells $(36 \%)$ and the nonlinear mode $(9 \%)$. Bow echoes accounted for a higher percentage in the Type- 2 cluster (16\%) compared to the Type-1 cluster (6\%). Thus, linear systems tend to be more common during the cold season and higher-shear environments. Nevertheless, in the highest shear environments (BSS-6KM exceeding about $30 \mathrm{~m} \mathrm{~s}^{-1}$ ), severe convective winds were produced from cells with relatively low surface temperatures and CAPE (Fig. 12). Given these cells occurred in the cool-season with low CAPE, it is unlikely they were supercells (Thompson et al. 2012). Therefore, supercells are not necessarily a requirement to produce severe convective winds from cells.

A surprising result is that only $10 \%$ of all European convective windstorms were bow echoes. Since Fujita (1978), bow echoes have been recognized as severe wind producers. Later studies from Klimowski et al. (2003), Gallus et al. (2008), and Duda and Gallus (2010) found that bow echoes were the dominant mode of severe convective wind events in the northern

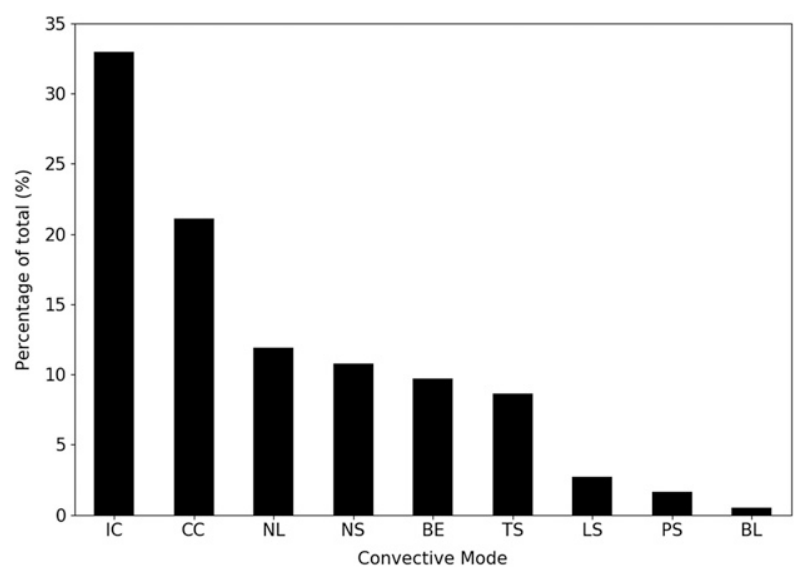

FIG. 10. Percentages of the 185 events shown in Fig. 8 classified into their convective storm modes. 


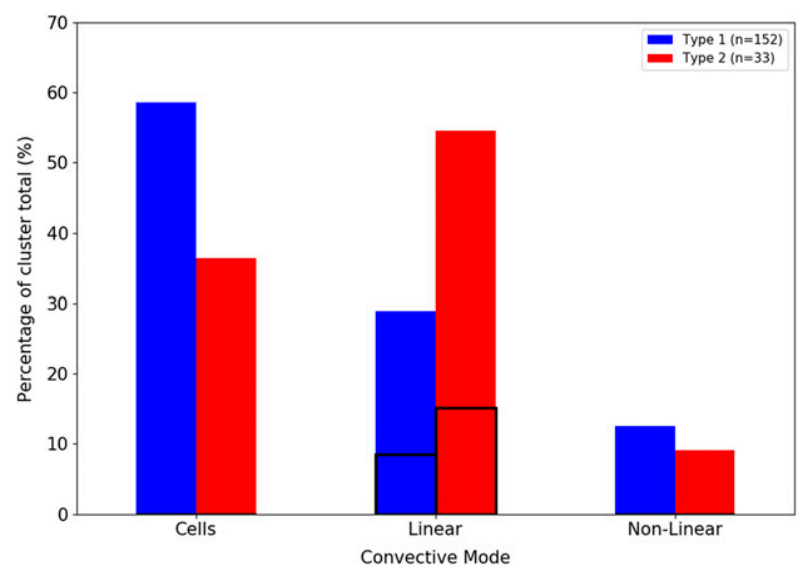

FIG. 11. Percentages of Type- 1 and Type- 2 events classified by convective mode, out of the 185 events shown in Fig. 8. Bow echoes are marked in black on the linear bars.

plains and the Midwestern United States, and even occur in the cold season over the United States (e.g., Burke and Schultz 2004). Nine percent of all severe convection events in the United States were bow echoes (Table 1 in Smith et al. 2012), whereas $58 \%$ of all warm-season severe wind reports in Germany were bow echoes. Gatzen (2013) found that only 15\% of warm-season severe wind events in Germany came from either isolated cells or supercells, whereas cellular systems account for $59 \%$ of all events in the present study. These results are surprising because the aforementioned severe convective wind mode studies were performed during the warm season. Here, events are included from the cold season where one might expect linear systems to be more frequent due to frontal systems and stronger shear. Despite differences in the construction of the climatology, provenance of the reports, and differences between windstorms in the United States and Europe, the forecasting implication of this result is important. Given the relatively small percentage of linear systems with bow echoes, extreme caution should be exercised by a forecaster waiting to see a bowing echo on radar before issuing a warning for severe convective winds.

\section{Summary}

Severe convective windstorms in Europe have been studied to determine their climatology, prestorm environments, and convective modes. A climatology was built based on 10233 quality-controlled and verified severe convective wind reports between 2009 and 2018. Severe convective wind reports and event days have steadily increased from 50 wind days $\mathrm{yr}^{-1}$ in

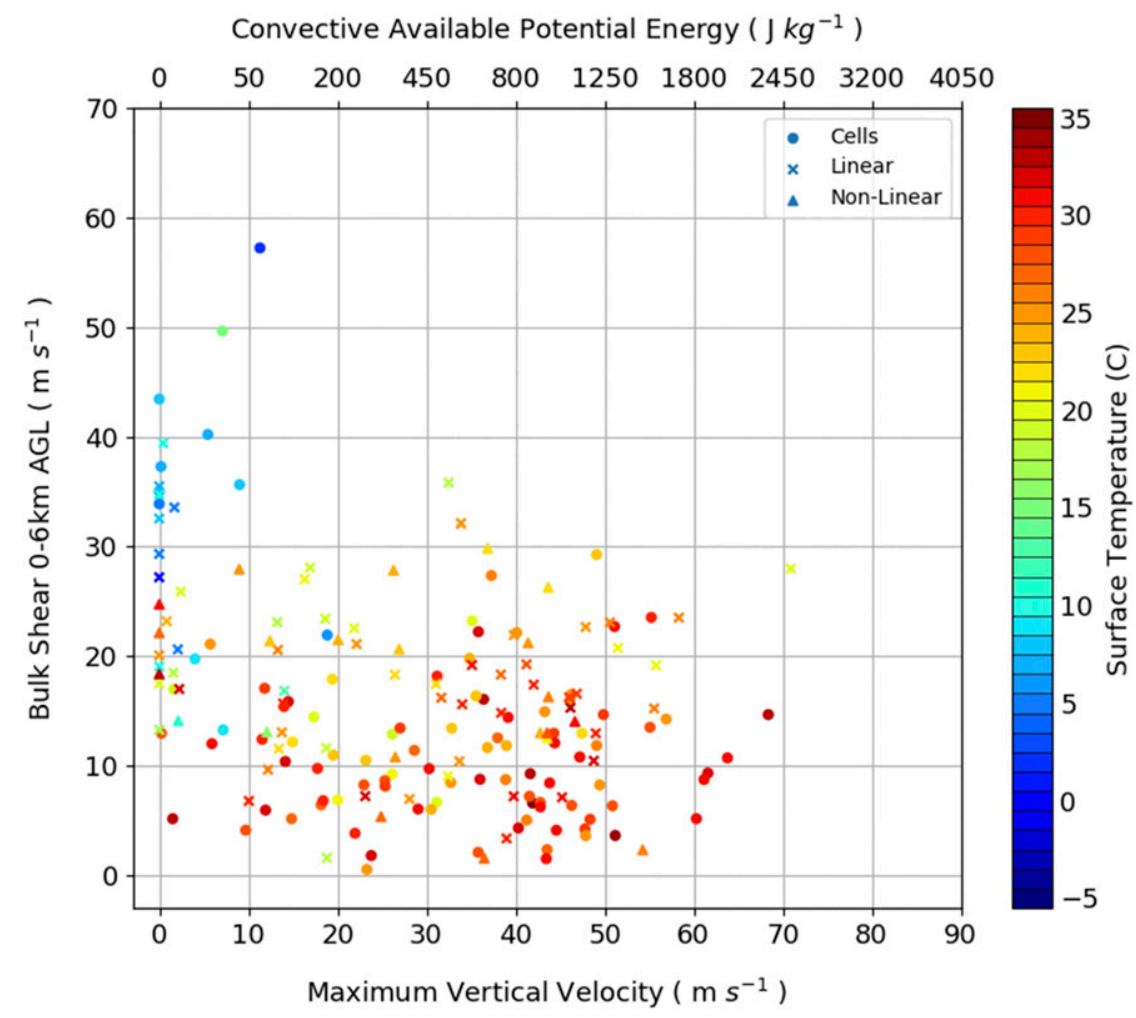

FIG. 12. Scatterplot of 0-6-km bulk shear (BSS-6KM) vs maximum vertical velocity and CAPE for the 185 events classified into their convective modes, with each point colored by the surface temperature. Maximum vertical velocity is calculated as $\sqrt{\text { 2CAPE}}$. Convective mode is indicated by the symbol in the legend: circles represent cells, crosses represent linear, and triangles represent nonlinear. 
2009 to 117 wind days in 2018 , largely because of the increase in reporting. Reporting was most frequent during the summer season where an event was reported every other day on average. Severe convective winds pose a threat to society Europewide and were reported in every country except Iceland.

The preconvective environment was assessed using 361 proximity soundings from 45 stations across Europe. A clustering technique was used on proximity soundings to separate and distinguish two different convective wind environments. The Type- 1 environment was characterized by moderate CAPE values (IQR $200-1040 \mathrm{~J} \mathrm{~kg}^{-1}$ ), with moderate values of bulk wind shear (IQR 10-20 $\mathrm{m} \mathrm{s}^{-1}$ ) and high surface temperatures (greater than $22^{\circ} \mathrm{C}$ for $90 \%$ of soundings). In this environment, DCAPE values were also moderate (IQR $700-1150 \mathrm{~J} \mathrm{~kg}^{-1}$ ). Type-1 windstorms tended to occur in the warm season. In contrast, Type- 2 environments were characterized by low CAPE (72\% exhibiting CAPE less than $100 \mathrm{~J} \mathrm{~kg}^{-1}$ ) with high to very high wind shear (IQR 21-39 $\mathrm{m} \mathrm{s}^{-1}$ ) and lower surface temperatures (IQR $7^{\circ}-17^{\circ} \mathrm{C}$ ). In this environment, the boundary layer was moister, lapse rates were less steep, and DCAPE values were lower. Type-2 windstorms tended to occur in the cold season.

A total of 185 events with proximity soundings between 2013 and 2018 were classified by their convective mode using radar data. Cells were the most frequent convective mode $(55 \%$ of events), followed by linear modes (33\%) and the nonlinear mode $(12 \%)$. Cells were the most frequent mode in Type- 1 environments, accounting for $58.5 \%$ of events, followed by linear modes $(29 \%)$ and the nonlinear mode $(12.5 \%)$. Drier boundary layers with steep lapse rates were present in this environment, which are indicative of an increased chance of severe convective winds. In Type- 2 environments, linear systems were the most frequent mode and accounted for $55 \%$ of events, followed by cells (36\%) and the nonlinear mode $(9 \%)$. Every mode from the classification scheme was identified at least once in the analysis, highlighting that severe convective winds can originate from a number of convective modes, and thus present a considerable challenge to forecasters. A relatively small percentage of all European convective windstorms were bow echoes $(10 \%)$. The environmental parameters analyzed in this study did not always distinguish well which convective mode was produced. However, cells producing severe convective winds predominantly developed in Type- 1 environments, whereas linear systems predominantly developed in Type-2 environments.

Acknowledgments. This article arose from Pacey's M.S. dissertation at the University of Manchester (Pacey 2020). We thank the European Severe Storms Laboratory (ESSL) for providing the ESWD data, the University of Wyoming for providing radiosonde data, OPERA for providing the radar data, the Met Office for providing the lightning data, and Prof. Daniel Kirshbaum for providing radar-data plotting code. We thank the three anonymous reviewers for their comments that improved the manuscript. Partial funding by Schultz was provided to the University of Manchester by the Natural Environment Research Council through Grant NE/N003918/1.
Data availability statement. Storm-event data were obtained through a license agreement from the European Severe Storm Database: http://www.eswd.eu. Radar data were obtained through a license agreement from OPERA: https://www.eumetnet.eu/ activities/observations-programme/current-activities/opera/. Sounding data were obtained from the University of Wyoming sounding archive: http://weather.uwyo.edu/upperair/sounding.html. Lightning data are proprietary and were provided courtesy of the Met Office (Met Office 2020).

\section{REFERENCES}

Antonescu, B., D. M. Schultz, F. Lomas, and T. Kühne, 2016: Tornadoes in Europe: Synthesis of the observational datasets. Mon. Wea. Rev., 144, 2445-2480, https://doi.org/10.1175/ MWR-D-15-0298.1.

__, —_, A. Holzer, and P. Groenemeijer, 2017: Tornadoes in Europe: An underestimated threat. Bull. Amer. Meteor. Soc., 98, 713-728, https://doi.org/10.1175/BAMS-D-160171.1.

,-- , H. M. A. M. Ricketts, and D. Ene, 2019: Theories on tornado and waterspout formation in ancient Greece and Rome. Wea. Climate Soc., 11, 889-900, https://doi.org/10.1175/ WCAS-D-19-0057.1.

Brooks, H., 2009: Proximity soundings for severe convection for Europe and the United States from reanalysis data. Atmos. Res., 93, 546-553, https://doi.org/10.1016/j.atmosres.2008.10.005.

— C. A. Doswell III, and J. Cooper, 1994: On the environments of tornadic and nontornadic mesocyclones. Wea. Forecasting, 9, 606-618, https://doi.org/10.1175/1520-0434(1994)009<0606: OTEOTA $>2.0 . \mathrm{CO} ; 2$.

_ , and Coauthors, 2019: A century of progress in severe convective storm research and forecasting. A Century of Progress in Atmospheric and Related Sciences: Celebrating the American Meteorological Society Centennial, Meteor. Monogr., No. 59, Amer. Meteor. Soc., https://doi.org/10.1175/AMSMONOGRAPHSD-18-0026.1.

Burke, P. C., and D. M. Schultz, 2004: A 4-yr climatology of coldseason bow echoes over the continental United States. Wea. Forecasting, 19, 1061-1074, https://doi.org/10.1175/811.1.

Celiński-Mysław, D., and D. Matuszko, 2014: An analysis of selected cases of derecho in Poland. Atmos. Res., 149, 263-281, https://doi.org/10.1016/j.atmosres.2014.06.016.

_ , and A. Palarz, 2017: The occurrence of convective systems with a bow echo in warm season in Poland. Atmos. Res., 193, 26-35, https://doi.org/10.1016/j.atmosres.2017.04.015.

,$- \ldots$, and M. Taszarek, 2020: Climatology and atmospheric conditions associated with cool season bow echo storms in Poland. Atmos. Res., 240, 104944, https://doi.org/10.1016/ j.atmosres.2020.104944.

Chmielewski, T., J. Szer, and P. Bobra, 2020: Derecho wind storm in Poland on 11-12 August 2017: Results of the post-disaster investigation. Environ. Hazards, 19, 508-528, https:/doi.org/ 10.1080/17477891.2020.1730154.

Clark, M., and D. Smart, 2016: Supercell and non-supercell tornadoes in the United Kingdom and Ireland. Extreme Weather: Forty Years of the Tornado and Storm Research Organization, R. K. Doe, Ed., John Wiley \& Sons, 31-59.

Cohen, A. E., M. C. Coniglio, S. F. Corfidi, and S. J. Corfidi, 2007: Discrimination of mesoscale convective system environments using sounding observations. Wea. Forecasting, 22, 1045-1062, https://doi.org/10.1175/WAF1040.1. 
Davis, J. M., and M. D. Parker, 2014: Radar climatology of tornadic and nontornadic vortices in high-shear, low-CAPE environments in the mid-Atlantic and southeastern United States. Wea. Forecasting, 29, 828-853, https://doi.org/10.1175/WAF-D-13-00127.1.

Doswell, C. A., III, 2003: Societal impacts of severe thunderstorms and tornadoes: Lessons learned and implications for Europe. Atmos. Res., 67-68, 135-152, https://doi.org/10.1016/S01698095(03)00048-6.

- 2005: Progress toward developing a practical societal response to severe convection (2005 EGU Sergei Soloviev Medal Lecture). Nat. Hazards Earth Syst. Sci., 5, 691-702, https://doi.org/10.5194/nhess-5-691-2005.

— , 2015: Severe convective storms in the European societal context. Atmos. Res., 158-159, 210-215, https://doi.org/ 10.1016/j.atmosres.2014.08.007.

— in forecasting severe storms. Electron. J. Severe Storms Meteor., 1 (3), https://ejssm.org/ojs/index.php/ejssm/article/ viewarticle/11/12.

- - H. E. Brooks, and R. A. Maddox, 1996: Flash flood forecasting: An ingredients-based methodology. Wea. Forecasting, 11, 560-581, https://doi.org/10.1175/1520-0434(1996)011<0560: FFFAIB $>2.0 . \mathrm{CO} ; 2$.

Dotzek, N., and C. Forster, 2011: Quantitative comparison of METEOSAT thunderstorm detection and nowcasting with in situ reports in the European Severe Weather Database (ESWD). Atmos. Res., 100, 511-522, https://doi.org/10.1016/ j.atmosres.2010.12.013.

- P. Groenemeijer, B. Feuerstein, and A. Holzer, 2009: Overview of ESSL's severe convective storms research using the European Severe Weather Database ESWD. Atmos. Res., 93, 575-586, https://doi.org/10.1016/j.atmosres.2008.10.020.

Duda, J. D., and W. A. Gallus Jr., 2010: Spring and summer Midwestern severe weather reports in supercells compared to other morphologies. Wea. Forecasting, 25, 190-206, https:// doi.org/10.1175/2009WAF2222338.1.

Evans, J. S., and C. A. Doswell III, 2001: Examination of derecho environments using proximity soundings. Wea. Forecasting, 16, 329-342, https://doi.org/10.1175/1520-0434(2001)016<0329: EODEUP $>2.0 . \mathrm{CO} ; 2$.

Fenelon, E. C., 1998: Doppler radar analysis of a microburst producing bow echo associated with a high shear and very low CAPE environment. 19th Conf. on Severe Local Storms, Minneapolis, MN, Amer. Meteor. Soc., 490-494.

Fujita, T., 1978: Manual of downburst identification for project Nimrod. Satellite and Mesometeorology Research Paper 156, $104 \mathrm{pp}$.

Gallus, W. A., Jr., N. A. Snook, and E. V. Johnson, 2008: Spring and summer severe weather reports over the Midwest as a function of convective mode: A preliminary study. Wea. Forecasting, 23, 101-113, https://doi.org/10.1175/2007WAF2006120.1.

Gatzen, C., 2004: A derecho in Europe: Berlin, 10 July 2002. Wea. Forecasting, 19, 639-645, https://doi.org/10.1175/ 1520-0434(2004)019<0639:ADIEBJ >2.0.CO;2.

- 2013: Warm-season severe wind events in Germany. Atmos. Res., 123, 197-205, https://doi.org/10.1016/j.atmosres.2012.07.017.

— A. H. Fink, D. M. Schultz, and J. G. Pinto, 2020: An 18-year climatology of derechos in Germany. Nat. Hazards Earth Syst. Sci., 20, 1335-1351, https://doi.org/10.5194/nhess-20-1335-2020.

Groenemeijer, P., and T. Kühne, 2014: A climatology of tornadoes in Europe: Results from the European Severe Weather Database. Mon. Wea. Rev., 142, 4775-4790, https://doi.org/ 10.1175/MWR-D-14-00107.1.
- - and Coauthors, 2017: Severe convective storms in Europe: Ten years of research and education at the European Severe Storms Laboratory. Bull. Amer. Meteor. Soc., 98, 2641-2651, https://doi.org/10.1175/BAMS-D-16-0067.1.

Hamid, K., 2012: Investigation of the passage of a derecho in Belgium. Atmos. Res., 107, 86-105, https://doi.org/10.1016/ j.atmosres.2011.12.013.

Huuskonen, A., E. Saltikoff, and I. Holleman, 2014: The operational weather radar network in Europe. Bull. Amer. Meteor. Soc., 95, 897-907, https://doi.org/10.1175/BAMS-D-12-00216.1.

Kaltenböck, R., G. Diendorfer, and N. Dotzek, 2009: Evaluation of thunderstorm indices from ECMWF analyses, lightning data and severe storm reports. Atmos. Res., 93, 381-396, https:// doi.org/10.1016/j.atmosres.2008.11.005.

King, J. R., M. D. Parker, K. D. Sherburn, and G. M. Lackmann, 2017: Rapid evolution of cool season, low-CAPE severe thunderstorm environments. Wea. Forecasting, 32, 763-779, https://doi.org/10.1175/WAF-D-16-0141.1.

Klimowski, B., M. Bunkers, M. Hjelmfelt, and J. Covert, 2003: Severe convective windstorms over the northern High Plains of the United States. Wea. Forecasting, 18, 502-519, https:// doi.org/10.1175/1520-0434(2003)18<502:SCWOTN>2.0.CO;2.

Krennert, T., R. Kaltenberger, G. Pistotnik, A. M. Holzer, F. Zeller, and M. Stampfl, 2018: Trusted spotter network Austria-A new standard to utilize crowdsourced weather and impact observations. Adv. Sci. Res., 15, 77-80, https://doi.org/10.5194/asr-15-77-2018.

Kuchera, E. L., and M. D. Parker, 2006: Severe convective wind environments. Wea. Forecasting, 21, 595-612, https://doi.org/ 10.1175/WAF931.1.

López, J., 2007: A Mediterranean derecho: Catalonia (Spain), 17th August 2003. Atmos. Res., 83, 272-283, https://doi.org/10.1016/ j.atmosres.2005.08.008.

Markowski, P., and Y. Richardson, 2010: Mesoscale Meteorology in Midlatitudes. Wiley, $407 \mathrm{pp}$.

Martius, O., M. Kunz, L. Nisi, and A. Hering, 2015: Conference report 1st European Hail Workshop. Meteor. Z., 24, 441-442, https://doi.org/10.1127/metz/2015/0667.

Mathias, L., V. Ermert, F. D. Kelemen, P. Ludwig, and J. G. Pinto, 2017: Synoptic analysis and hindcast of an intense bow echo in western Europe: The 9 June 2014 storm. Wea. Forecasting, 32, 1121-1141, https://doi.org/10.1175/WAFD-16-0192.1.

Met Office, 2020: Lightning strike location data. Met Office, 3 pp., https://www.metoffice.gov.uk/binaries/content/assets/ metofficegovuk/pdf/data/adtnet_data_sheet.pdf.

Morel, C., and S. Senesi, 2002: A climatology of mesoscale convective systems over Europe using satellite infrared imagery. II: Characteristics of European mesoscale convective systems. Quart. J. Roy. Meteor. Soc., 128, 1973-1995, https://doi.org/ $10.1256 / 003590002320603494$.

Mulder, K. J., and D. M. Schultz, 2015: Climatology, storm morphologies, and environments of tornadoes in the British Isles: 1980-2012. Mon. Wea. Rev., 143, 2224-2240, https://doi.org/ 10.1175/MWR-D-14-00299.1.

Pacey, G. P., 2020: Environments conducive for severe convective winds in Europe. M.S. dissertation, Centre for Atmospheric Science, Department of Earth and Environmental Sciences, University of Manchester, 46 pp., https://www.research. manchester.ac.uk/portal/files/173342047/FULL_TEXT.PDF.

Parker, M. D., and R. H. Johnson, 2000: Organizational modes of midlatitude mesoscale convective systems. Mon. Wea. Rev., 128, 3413-3436, https://doi.org/10.1175/1520-0493(2001) 129<3413:OMOMMC $>2.0 . \mathrm{CO} ; 2$. 
Potvin, C. K., K. L. Elmore, and S. J. Weiss, 2010: Assessing the impacts of proximity sounding criteria on the climatology of significant tornado environments. Wea. Forecasting, 25, 921930, https://doi.org/10.1175/2010WAF2222368.1.

Púčik, T., P. Groenemeijer, D. Rýva, and M. Kolár̆, 2015: Proximity soundings of severe and nonsevere thunderstorms in central Europe. Mon. Wea. Rev., 143, 4805-4821, https:// doi.org/10.1175/MWR-D-15-0104.1.

— C. Castellano, P. Groenemeijer, T. Kühne, A. Rädler, B. Antonescu, and E. Faust, 2019: Large hail incidence and its economic and societal impacts across Europe. Mon. Wea. Rev., 147, 3901-3916, https://doi.org/10.1175/MWR-D-19-0204.1.

Punge, H., and M. Kunz, 2016: Hail observations and hailstorm characteristics in Europe: A review. Atmos. Res., 176-177, 159-184, https://doi.org/10.1016/j.atmosres.2016.02.012.

—, K. Bedka, M. Kunz, and A. Reinbold, 2017: Hail frequency estimation across Europe based on a combination of overshooting top detections and the ERA-INTERIM reanalysis. Atmos. Res., 198, 34-43, https://doi.org/10.1016/j.atmosres.2017.07.025.

Punkka, A., J. Teittinen, and R. Johns, 2006: Synoptic and mesoscale analysis of a high-latitude derecho-severe thunderstorm outbreak in Finland on 5 July 2002. Wea. Forecasting, 21, 752763, https://doi.org/10.1175/WAF953.1.

Rasmussen, E. N., and D. O. Blanchard, 1998: A baseline climatology of sounding-derived supercell and tornado forecast parameters. Wea. Forecasting, 13, 1148-1164, https://doi.org/ 10.1175/1520-0434(1998)013<1148:ABCOSD > 2.0.CO;2.

Saltikoff, E., and Coauthors, 2019: OPERA the Radar Project. Atmosphere, 10, 320, https://doi.org/10.3390/atmos10060320.

Schoen, J. M., and W. S. Ashley, 2011: A climatology of fatal convective wind events by storm type. Wea. Forecasting, 26, 109-121, https://doi.org/10.1175/2010WAF2222428.1.

Sherburn, K. D., and M. D. Parker, 2014: Climatology and ingredients of significant severe convection in high-shear, lowCAPE environments. Wea. Forecasting, 29, 854-877, https:// doi.org/10.1175/WAF-D-13-00041.1.

— — - J. R. King, and G. M. Lackmann, 2016: Composite environments of severe and nonsevere high-shear, low-CAPE convective events. Wea. Forecasting, 31, 1899-1927, https:// doi.org/10.1175/WAF-D-16-0086.1.

Smith, B., R. Thompson, J. Grams, C. Broyles, and H. Brooks, 2012: Convective modes for significant severe thunderstorms in the contiguous United States. Part I: Storm classification and climatology. Wea. Forecasting, 27, 1114-1135, https://doi.org/ 10.1175/WAF-D-11-00115.1.

_ T. T. Castellanos, A. C. Winters, C. M. Mead, A. R. Dean, and R. L. Thompson, 2013: Severe convective wind climatology and associated convective modes of thunderstorms in the contiguous United States, 2003-09. Wea. Forecasting, 28, 229236, https://doi.org/10.1175/WAF-D-12-00096.1.

Surowiecki, A., and M. Taszarek, 2020: A 10-year radar-based climatology of mesoscale convective system archetypes and derechos in Poland. Mon. Wea. Rev., 148, 3471-3488, https:// doi.org/10.1175/MWR-D-19-0412.1.

Taszarek, M., and H. E. Brooks, 2015: Tornado climatology of Poland. Mon. Wea. Rev., 143, 702-717, https://doi.org/10.1175/ MWR-D-14-00185.1.

— — - and B. Czernecki, 2017: Sounding-derived parameters associated with convective hazards in Europe. Mon. Wea. Rev., 145, 1511-1528, https://doi.org/10.1175/MWR-D-16-0384.1.

,,,--- P. Szuster, and K. Fortuniak, 2018: Climatological aspects of convective parameters over Europe: A comparison of ERA-Interim and sounding data. J. Climate, 31, 4281-4308, https://doi.org/10.1175/JCLI-D-17-0596.1.

— , and Coauthors, 2019a: A climatology of thunderstorms across Europe from a synthesis of multiple data sources. J. Climate, 32, 1813-1837, https://doi.org/10.1175/JCLI-D-18-0372.1.

— , and Coauthors, 2019b: Derecho evolving from a mesocyclone-A study of 11 August 2017 severe weather outbreak in Poland: Event analysis and high-resolution simulation. Mon. Wea. Rev., 147, 2283-2306, https://doi.org/10.1175/MWR-D-18-0330.1.

Thompson, R. L., B. T. Smith, J. S. Grams, A. R. Dean, and C. Broyles, 2012: Convective modes for significant severe thunderstorms in the contiguous United States. Part II: Supercell and QLCS tornado environments. Wea. Forecasting, 27, 1136-1154, https://doi.org/10.1175/WAF-D-11-00116.1.

Toll, V., A. Männik, A. Luhamaa, and R. Rõõm, 2015: Hindcast experiments of the derecho in Estonia on 08 August, 2010: Modelling derecho with NWP model HARMONIE. Atmos. Res., 158-159, 179-191, https://doi.org/10.1016/j.atmosres.2014.10.011.

Trapp, R. J., S. A. Tessendorf, E. S. Godfrey, and H. E. Brooks, 2005: Tornadoes from squall lines and bow echoes. Part I: Climatological distribution. Wea. Forecasting, 20, 23-34, https://doi.org/10.1175/WAF-835.1.

Tudurí, E., and C. Ramis, 1997: The environments of significant convective events in the western Mediterranean. Wea. Forecasting, 12, 294-306, https://doi.org/10.1175/1520-0434(1997) 012<0294:TEOSCE > 2.0.CO;2.

van den Broeke, M. S., D. M. Schultz, R. H. Johns, J. S. Evans, and J. E. Hales, 2005: Cloud-to-ground lightning production in strongly forced, low-instability convective lines associated with damaging wind. Wea. Forecasting, 20, 517-530, https:// doi.org/10.1175/WAF876.1.

Weisman, M. L., and J. B. Klemp, 1982: The dependence of numerically simulated convective storms on vertical wind shear and buoyancy. Mon. Wea. Rev., 110, 504-520, https://doi.org/ 10.1175/1520-0493(1982)110<0504:TDONSC >2.0.CO;2.

Wilks, D. S., 2006: Statistical Methods in the Atmospheric Sciences. 2nd ed. International Geophysics Series, Vol. 100, Academic Press, 648 pp.

Yang, X., and J. Sun, 2018: Organizational modes of severe wind-producing convective systems over North China. $A d v$. Atmos. Sci., 35, 540-549, https://doi.org/10.1007/s00376017-7114-2. 